\title{
Microbiological evaluation of protein quality with Tetrahymena pyriformis $\mathrm{W}$
}

\author{
3.* A simplified assay procedure \\ BY J. A. STOTT AND H. SMITH \\ Research Department, $\mathscr{7}$. Bibby and Sons Ltd, King Edward Street, Liverpool 3 \\ AND G. D. ROSEN \\ International Protein Products Ltd, 168-173 High Holborn, London, W.C. I
}

(Received 27 August 1962-Revised 17 December 1962)

Methods for assessing the nutritive characteristics of proteins range from feeding trials using practical mixed diets with human and animal subjects to the laboratory evaluation of a single chemical property, such as the methionine content, of a single protein source. Between these two extremes there are, for example, rat and chick assays designed as biological screening tests for single protein sources. Biological tests with these species are relatively expensive and time-consuming, but nevertheless they do encompass digestibility and amino acid availability. The 'available lysine' test of Carpenter, Ellinger, Munro \& Rolfe (1957) is so far the only purely chemical test designed to measure available as opposed to total amino acid content, and with the other amino acids the need for a biological test is becoming increasingly apparent.

Microbiological assays of intact proteins make it possible to do a large number of rapid and comparatively inexpensive biological assays, with due emphasis on the availability of essential amino acids. The scope and potentialities of such tests have been reviewed by Rosen (1959), Ford (I960) and Rosen, Stott \& Smith (1960) and it is sufficient here to emphasize the double role of microbiological assays for measuring either the overall nutritive value of protein or the availability of individual essential amino acids.

Previous work demonstrated the ability of Tetrahymena pyriformis $\mathrm{W}$ to utilize a wide variety of protein sources, and it was shown that the relative nutritive values of the various types of protein source were generally similar to those for the growing rat (Fernell \& Rosen, 1956; Rosen \& Fernell, 1956). Modified techniques have since been applied to an extended range of materials and to the study of several aspects of the organism's metabolism and protein nutrition (Rosen et al. 1960). The measurement of organism response adopted by Rosen \& Fernell (1956) was devised to determine the efficiency of protein utilization as expressed by the ratio of the number of organisms per $\mathrm{ml}$ culture medium to the amount of ammonia nitrogen present after 4 days' incubation. This approach was adopted because, under the chosen cultural conditions, a linear relationship between growth and protein level was not obtained. Later

\footnotetext{
* Paper no. 2: Brit. F. Nutr. (1956), 10, 156.
} 
work on cereals and on protein concentrates damaged by heat (Rosen, 1959; Rosen et al. 1960) revealed that the ratio, count:ammonia $\mathrm{N}$ could give anomalous results under some conditions, and the possibility of using organism count as the criterion of nutritive value was considered. Further work confirming the value of the criterion and thus leading to simplification of the assay procedure is described in this paper.

\section{EXPERIMENTAL}

In previous work with $0.5 \mathrm{mg} \mathrm{N} / \mathrm{ml}$ culture medium, the medium contained either $2 \%$ starch or $0.75 \%$ glucose. As a preliminary part of the work now described these two carbohydrates at these two levels were used in assays of fish meals and meat meals with $\mathrm{N}$ contents ranging from $0 . \mathrm{I}$ to $0.5 \mathrm{mg} \mathrm{N} / \mathrm{ml}$ culture medium. Later a study was made with media containing $0.75 \%$ glucose and the $\mathrm{r} \cdot 5 \%$ originally used by Rosen 8 Fernell (1956) for assays with $1.0 \mathrm{mg} \mathrm{N} / \mathrm{ml}$.

To determine a suitable $\mathrm{N}$ level for assays in which growth (count) alone would suffice as the index of nutritive value, growth response of $T$. pyriformis $\mathrm{W}$ with meat meal, fish meal, dried whole egg, soya-bean meal, groundnut meal and wheat was measured over the range $0.1-0.5 \mathrm{mg} \mathrm{N} / \mathrm{ml}$ assay medium.

In general the method followed that of Rosen \& Fernell (1956) but, after the studies on the relationship of growth to $\mathrm{N}$ level had been completed, the measurement of ammonia $\mathrm{N}$ was omitted. The simplified assay procedure was:

(I) The test material was extracted three times with diethyl ether at room temperature and once with industrial methylated spirit ( $74 \%$ over-proof). The material was finally washed with ether to remove residual alcohol and air-dried at room temperature. The dried material was then ground to pass a 72-mesh BS sieve. (The extraction and washing may be omitted for meals known to have been extracted with solvent.)

(2) The $\mathrm{N}$ content of the ground test material was determined by the Kjeldahl method, the digestion procedure of Chibnall, Rees \& Williams (I943) and the steam-distillation procedure of Markham (1942) being used. The ammonia was distilled into Io $\mathrm{ml}$ of I $\%(\mathrm{w} / \mathrm{v})$ boric acid, and $0.1 \mathrm{~N}-\mathrm{HCl}$ was used for titration with a methylene bluemethyl red indicator (Yuen \& Pollard, 1953). Suspensions of test material were then prepared to give a $\mathrm{N}$ content of $\mathrm{I}-5 \mathrm{mg} / 4 \mathrm{ml}(3 \mathrm{mg} / 4 \mathrm{ml}$ in routine assays) and the $\mathrm{pH}$ was adjusted to $8 \cdot 2$.

(3) Stock solutions A, B, C and D, all roo times as strong as in the final medium, were prepared as shown in Table I. Solution E, which was five times as strong as in the final medium, was then prepared from B, C, D and the appropriate weights of guanylic acid (sodium salt), adenosine- $2^{\prime}\left(3^{\prime}\right)$-phosphoric acid, cytidylic acid and uracil given in Table $\mathrm{I}$. This solution was adjusted to $\mathrm{pH} 8 \cdot 2$. In the earlier work (Fernell \& Rosen, I95 $^{6}$ ) the $\mathrm{pH}$ used was $7 \cdot \mathrm{I}$, but $8 \cdot 2$ was now adopted to eliminate any tendency for the $\mathrm{pH}$ to drop below $7 \cdot \mathrm{I}$ when solution $\mathrm{E}$ plus protein suspension was autoclaved. With this modification the level of phosphate in the medium was reduced to that originally proposed by Fernell \& Rosen (1956).

(4) Into each of a series of $2 \mathrm{oz}$ 'medical flat' screw-capped bottles were pipetted: 
(a) $2 \mathrm{ml}$ of solution E; (b) $4 \mathrm{ml}$ of $2 \cdot 5$ times strength test-material suspension; (c) $2 \mathrm{ml}$ of distilled water (which volume may be used for the addition of supplementary amino acids). The bottles were then autoclaved at $121^{\circ}$ for $10 \mathrm{~min}$, the time being reduced from the 15 min used previously to minimize the possibility of thermal damage to amino acids.

\section{Table 1. Composition of stock solutions and solution $E$}

Stock solution A (roo times final
strength)
Calcium pantothenate
Nicotinamide
Pyridoxine hydrochloride
Pyridoxal hydrochloride
Pyridoxamine hydrochloride
Riboflavin
Folic acid
Thiamine hydrochloride
Inositol
Choline chloride
p-Aminobenzoic acid
Biotin
DL- $\alpha$-lipoic acid
$\mathrm{Stock} \mathrm{solution} \mathrm{B}\left(100\right.$ times final $_{\text {strength) }}$
$\mathrm{MgSO}_{4} \cdot 7 \mathrm{H}_{2} \mathrm{O}$
$\mathrm{Fe}\left(\mathrm{NH}_{4}\right)_{2}\left(\mathrm{SO}_{4}\right)_{2} \cdot 6 \mathrm{H}_{2} \mathrm{O}$
$\mathrm{MnCl}_{2} \cdot 4 \mathrm{H}_{2} \mathrm{O}$
$\mathrm{ZnCl}_{2}$

$(\mathrm{mg} / 200 \mathrm{ml})$
$12 \cdot 5$
$12 \cdot 5$
$125 \cdot 0$
$12 \cdot 5$
$12 \cdot 5$
12.5
$1 \cdot 25$
$125 \cdot 0$
$12 \cdot 5$
$125 \cdot 0$
$12 \cdot 5$
$1 \cdot 25$
0.4
$(\mathrm{g} / 200 \mathrm{ml})$
I.25
0.025
0.0025

\begin{tabular}{|c|c|}
\hline $\begin{array}{l}\text { tock solution } \mathrm{C} \text { (100 times final } \\
\text { strength) } \\
\mathrm{CaCl}_{2} \cdot 2 \mathrm{H}_{2} \mathrm{O} \\
\mathrm{CuCl}_{2} \cdot 2 \mathrm{H}_{2} \mathrm{O} \\
\mathrm{FeCl}_{3} \cdot 6 \mathrm{H}_{2} \mathrm{O}\end{array}$ & $\begin{array}{l}(\mathrm{mg} / 200 \mathrm{ml}) \\
600 \\
60 \\
15\end{array}$ \\
\hline $\begin{array}{l}\text { tock solution } \mathrm{D} \text { (roo times final } \\
\text { strength) } \\
\mathrm{KH}_{2} \mathrm{PO}_{4} \\
\mathrm{~K}_{2} \mathrm{HPO}_{4}\end{array}$ & $\begin{array}{c}(\mathrm{g} / 200 \mathrm{ml}) \\
3.5 \\
3.5\end{array}$ \\
\hline $\begin{array}{l}\text { Solution } \mathrm{E} \text { ( } 5 \text { times final strength) } \\
\text { (The appropriate weights of the co } \\
\text { listed below are dissolved in approxir } \\
\text { 10 } \mathrm{ml} \text { distilled water, } 1 \mathrm{ml} \text { stock solu } \\
\mathrm{C}, \mathrm{D} \text { added and the whole made up }\end{array}$ & $\begin{array}{l}\text { omponents } \\
\text { imately } \\
\text { ations } \mathrm{B} \text {, } \\
\text { to } 20 \mathrm{ml} \text { ) } \\
\mathrm{mg} / 20 \mathrm{ml} \\
\text { solution } \mathrm{E}\end{array}$ \\
\hline $\begin{array}{l}\text { Guanylic acid (sodium salt) } \\
\text { Adenosine-2' }\left(3^{\prime}\right) \text {-phosphoric acid } \\
\text { monohydrate }\end{array}$ & $\begin{array}{l}\text { I5 } \\
\text { 10 }\end{array}$ \\
\hline $\begin{array}{l}\text { Cytidylic acid } \\
\text { Uracil }\end{array}$ & $\begin{array}{c}12 \cdot 5 \\
5\end{array}$ \\
\hline
\end{tabular}

(5) Two solutions were autoclaved separately at $12 \mathrm{I}^{\circ}$ for $\mathrm{Io} \min :(a)$ the stock vitamin solution A (Table I) diluted ten times; $(b)$ a solution containing $15 \%(\mathrm{w} / \mathrm{v})$ glucose. This concentration of glucose was ten times that in the final medium.

(6) To each bottle after cooling were added aseptically I $\mathrm{ml}$ diluted solution $\mathrm{A}$ and I ml glucose solution.

(7) Assays were made with three replicates for each meal.

(8) Each bottle was inoculated with three drops of a 3-day broth culture of $T$. pyriformis $\mathrm{W}$, and incubated at $25^{\circ}$ for 4 days. The screw caps were left loose during this period and the bottles were inclined at $15^{\circ}$ to the horizontal to provide sufficient aeration for rapid growth.

(9) After 4 days' incubation, the cultures were shaken for $2 \mathrm{~min}$ on a flask shaker and I $\mathrm{ml}$ of culture was transferred to a $\frac{1}{4} \mathrm{oz}$ screw-capped bottle containing I $\mathrm{ml}$ preserving fluid (consisting of $90 \mathrm{ml}$ water, $20 \mathrm{ml} 36 \%$ (w/v) formaldehyde and to $\mathrm{ml}$ of stock solution D).

(Io) Organisms were counted in a single-cell haemocytometer with FuchsRosenthal ruling to $\mathrm{BS} 74^{8}$. The organisms in eight alternate $\mathrm{I} \mathrm{mm}$ squares were counted and the mean number per I $\mathrm{mm}$ square gave the final population of the test culture in units of $10^{4}$ organisms $/ \mathrm{ml}$. This figure was used to express the nutritive value of the protein in test materials. 


\section{RESULTS AND DISCUSSION}

\section{Choice of carbohydrate source}

Comparison of $2 \%$ starch and $0.75 \%$ glucose as carbohydrate sources over the range $0.1-0.5 \mathrm{mg} \mathrm{N} / \mathrm{ml}$ culture medium showed that glucose usually gave a higher count figure than starch, as exemplified in Fig. I. The use of starch also increased the opacity of the medium and thus rendered counting of the organisms somewhat more difficult than in the presence of glucose. These factors led to the adoption of glucose for routine assays. The further comparison of 0.75 and $1.5 \%$ glucose over the range $0.1-0.5 \mathrm{mg} \mathrm{N} / \mathrm{ml}$ showed no difference in count, and $1.5 \%$ was therefore selected to ensure an ample carbon and energy supply in the basal medium.

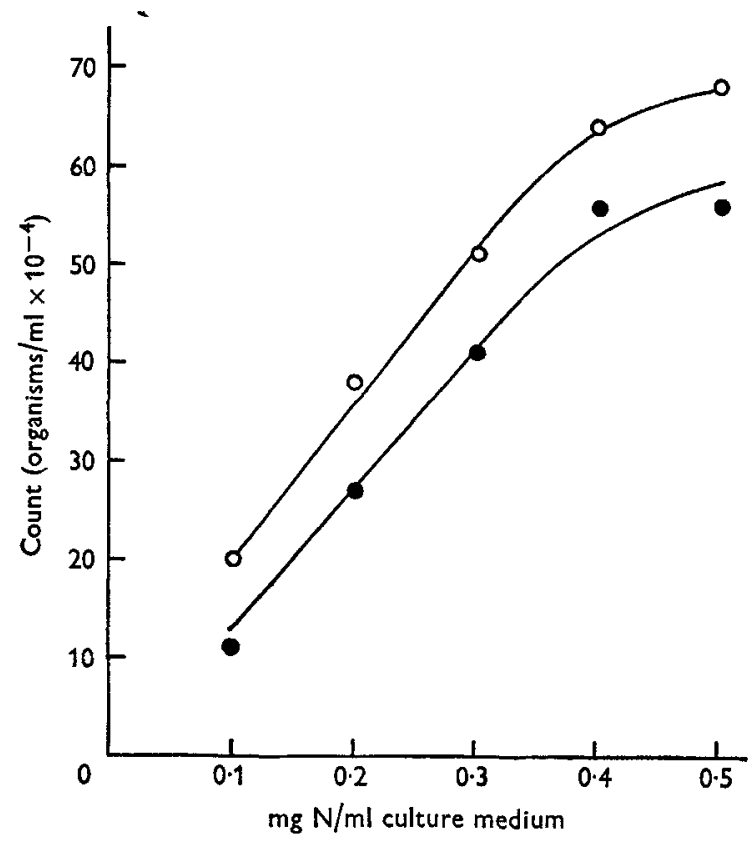

Fig. I. Growth response of T. pyriformis $\mathrm{W}$ at low nitrogen levels, with glucose or starch as the energy source. $0,0 \cdot 75 \%$ glucose; $\bullet, 2 \%$ starch.

In contrast to assays of simple protein sources, assays of mixed feeds, such as broiler, turkey and pig feeds, alone or in the presence of added starch or glucose, gave similar count values, indicating that the carbohydrate in the feed was itself sufficient for the energy requirements of the organism. However, since some mixed feeds intended for young animals, notably pigs and calves, may contain an appreciable proportion of lactose, which is not utilized by $T$. pyriformis $\mathrm{W}$ (unpublished findings), we have adopted $1.5 \%$ glucose for routine assays of animal feeds.

\section{Growth response at low $N$ levels}

The growth response of $T$. pyriformis $\mathrm{W}$ with fish meal, meat meal, dried whole egg, soya-bean meal, groundnut meal and wheat is shown in Fig. 2, the sample code 
numbers being those adopted for a collaborative investigation organized by the Agricultural Research Council (Boyne, Carpenter \& Woodham, 196r). It will be seen that a straight-line response was obtained between 0.1 and $0.4 \mathrm{mg} \mathrm{N} / \mathrm{ml}$, which indicates that up to this point the growth of the organism was linearly related to the

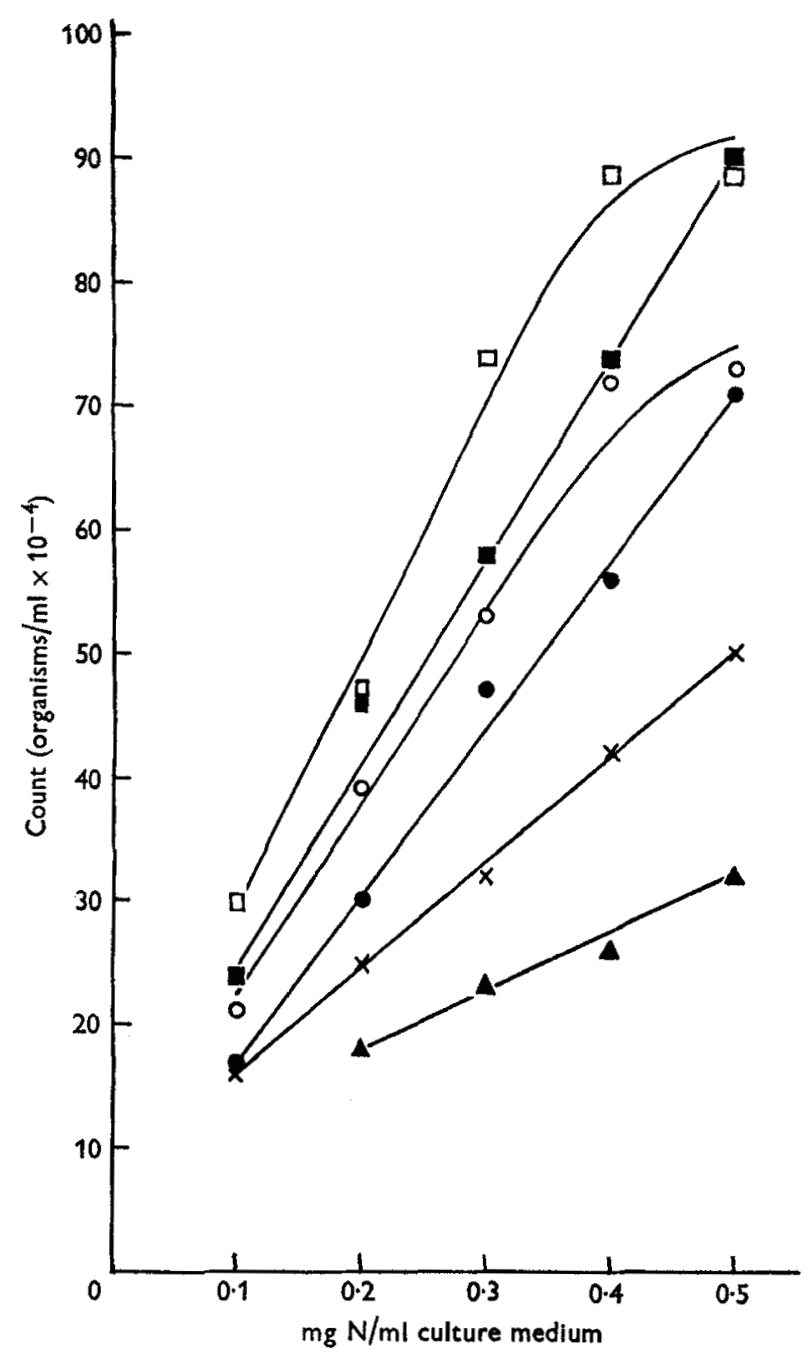

Fig. 2. Growth response of $T$. pyriformis $\mathrm{W}$ at low nitrogen levels to various protein sources. $\square$, egg; $\omega$, soya-bean meal SB ${ }^{*}$; $\circ$, fish meal $\mathrm{FM}_{2}^{*}$; $\bullet$, meat meal MMI*; $\times$, groundnut meal GN $5^{*} ; \wedge$, wheat.

*Sample code number used by Boyne et al. 196r.

amount of protein present. A concentration of $0.3 \mathrm{mg} \mathrm{N} / \mathrm{ml}$ culture medium was chosen as a level at which the number of organisms present after 4 days' incubation would provide a suitable routine measure of the nutritive value of proteins.

The response curves in Fig 2 show similar nutritive values for the various protein sources over the range $0.1-0.4 \mathrm{mg} \mathrm{N} / \mathrm{ml}$, with the exception of the curves for groundnut meal and wheat, in which there is some suggestion of an influence of $\mathrm{N}$ level on 
nutritive value. However, the count values for groundnut meal at $0.1 \mathrm{mg} \mathrm{N} / \mathrm{ml}$ and for wheat at $0.2 \mathrm{mg} \mathrm{N} / \mathrm{ml}$ are so low that an error of as little as one organism per $\mathrm{I} \mathrm{mm}$ square of the counting chamber alters the apparent nutritive value by some $6 \%$, and it is thus quite probable that the divergence of nutritive values for groundnut and wheat over the $\mathrm{N}$ levels used is not significant.

\section{Survey of protein sources}

A wide range of protein sources has now been assayed with $T$. pyriformis $\mathrm{W}$ to determine the nutritive value with the simpler criterion of organism count. The range of values obtained in assays at $0.3 \mathrm{mg} \mathrm{N} / \mathrm{ml}$ for various types of protein sources is given in Table 2. Results for some of the samples examined as part of the collaborative study already mentioned (Boyne et al. 1961) are included.

Table 2. Nutritive value of protein in various sources determined with Tetrahymena pyriformis $W$, with a concentration of $0.3 \mathrm{mg}$ nitrogen $/ \mathrm{ml}$ culture medium and with $\mathrm{I} \cdot 5 \%$ glucose in the medium

\begin{tabular}{lc}
\multicolumn{1}{c}{ Protein source } & Count (organisms $/ \mathrm{ml} \times \mathrm{ro}^{-4}$ ) \\
Egg & 77 (I) \\
Casein & $59-66$ (2) \\
Yeast & $38-51$ (2) \\
Meat meal & $28-62(\mathrm{I4})$ \\
Fish meal & $15-64(35)$ \\
Whale-meat meal & $26-38(4)$ \\
Soya-bean meal & $49-68(\mathrm{Ir})$ \\
Groundnut meal & $34-46(\mathrm{Ir})$ \\
Cottonseed meal & $29-32(2)$ \\
Sunflower-seed meal & $29-36(3)$ \\
Wheat & $20-36(3)$ \\
Maize & $18-22(2)$ \\
Barley & $16-29(3)$
\end{tabular}

Figures in parentheses are the number of samples assayed.

It will be seen that $T$. pyriformis assays graded egg as the best protein source, with casein and the best soya-bean, fish and meat meals of equal value farther down the scale. But it is significant that some animal protein sources were inferior to the worst samples of vegetable protein concentrates. Also there are whale-meat meals of higher nutritive value than those used in this particular study (Rosen et al. 1960). In general, fish meals and meat meals showed a wider range of nutritive value than the soya-bean and groundnut meals. The greater uniformity of these vegetable protein sources may derive in part from a lesser variation in the raw materials used in their manufacture and in part also from research on the technology of oilseed processing, which has enabled manufacturers to minimize damage by heat during processing.

Boyne et al. (1961), considering thirteen of the results for meat meals included in Table 2, noted that nutritive values determined with $T$. pyriformis showed a correlation with available lysine values (Carpenter et al. 1957) which was significant at the $5 \%$ level, and also noted a correlation with gross protein values (Heiman, Carver \& Cook, 1939) determined by chick-feeding tests. T. pyriformis results for eighteen 
fish meals reviewed by the same authors showed no correlation with available lysine values, presumably because lysine was not the limiting amino acid for $T$. pyriformis in these meals.

Supplementation of protein sources by amino acids evoked various responses from $T$. pyriformis with the simplified procedure. The count value for wheat was increased from 24 to 53 by addition of $1 \%$ L-lysine. Barley, oats and rice also gave increased growth with added lysine, but maize and soya-bean did not. Soya-bean meal showed the expected methionine deficiency, with a small increase in organism count from 55 to 62 on addition of $2.5 \%$ L-methionine. Also, after a soya-bean meal had been heated for $I_{2}^{1} \mathrm{~h}$ at $121^{\circ}$, assays showed no increase in growth on addition of lysine or methionine separately, but growth did increase with the addition of the two amino acids together. Further heating for $\mathrm{I} \mathrm{h}$ at $\mathrm{I} 2 \mathrm{I}^{\circ}$ resulted in lysine alone becoming the limiting amino acid in the meal.

\section{SUMMARY}

I. A simplified procedure for assay of the nutritive value of proteins with Tetrahymena pyriformis $\mathrm{W}$ is described.

2. The organism count after 4 days' incubation was used as a simple criterion of the nutritive value of protein.

3. Modifications of the cultural conditions, compared with those used by Rosen \& Fernell (1956), were a reduction in the amount of phosphate in the basal medium and adjustment of meal suspension to $\mathrm{pH} 8 \cdot 2$ before autoclaving.

4. For assays of protein concentrates and mixed animal feeding-stuffs the nitrogen level in the medium was reduced to $0.3 \mathrm{mg} / \mathrm{ml}$.

5. Glucose was found to be a more suitable energy source for routine assays than starch.

6. Results of assays on ninety-three protein foodstuffs illustrated the wide variation in nutritive value of individual types, especially fish meals and meat meals.

7. Typical improvements in the nutritive value of certain vegetable proteins when supplemented with lysine and methionine were observed with the simplified procedure.

\section{REFERENCES}

Boyne, A. W., Carpenter, K. J. \& Woodham, A. A. (196r). F. Sci. Fd Agric. r2, 832.

Carpenter, K. J., Ellinger, G. M., Munro, M. I. \& Rolfe, E. J. (I957). Brit. F. Nutr. rז, I62.

Chibnall, A. C., Rees, M. W. \& Williams, E. F. (1943). Biochem. F. 37, 354.

Fernell, W. R. \& Rosen, G. D. (1956). Brit. F. Nutr. 1o, 143.

Ford, J. E. (1960). Brit. F. Nutr. 14, 485.

Heiman, V., Carver, J. S. \& Cook, J. W. (1939). Poult. Sci, 18, 464.

Markham, R. (1942). Biochem. F. 36, 790.

Rosen, G. D. (1959). Proceedings of the International Symposium on Micro-chemistry 1958, p. 212. London: Pergamon Press.

Rosen, G. D. \& Fernell, W. R. (1956). Brit. $\mathcal{~ Y . ~ N u t r . ~ r o , ~} 156$.

Rosen, G. D., Stott, J. \& Smith, H. (1960). Proceedings of the Pfizer European Agricultural Research Conference, p. 368. [J. Vernon and G. D. Rosen, editors.]

Yuen, S. H. \& Pollard, A. G. (1953). 7. Sci. Fd Agric. 4, 490. 